\title{
The Social and Economic Life of Fishermen Maccini Sombala, Makassar City
}

\author{
Muh. Rasyid Ridha* \\ Departemen of History Education \\ Faculty of Social Science \\ State University of Makassar \\ Makassar, Indonesia \\ rasyidridha@unm.ac.id
}

\author{
Amirullah \\ Departemen of History Education \\ Faculty of Social Science \\ Universitas Negeri Makassar \\ Makassar, Indonesia \\ amirullah8505@unm.ac.id
}

\author{
Ahmadin \\ Departemen of History Education \\ Faculty of Social Science \\ Universitas Negeri Makassar \\ Makassar, Indonesia \\ ahmadin@unm.ac.id
}

\begin{abstract}
The development of the socio-economic life of Maccini Sombala fishermen in Makassar City is very much influenced by the geographical aspect where they live, especially in terms of the pattern of fisheries business development. The results showed that Maccini Sombala fishermen are difficult to develop, their social and economic life is still very dependent on natural and weather conditions. far due to the construction and stockpiling of the coast along the Tanjung Bunga metro road, even the place where their boats are moored is no longer due to the construction of the Tanjung Bunga Metro road and it is no longer possible for them to survive, the choice as fishermen for now is only because there are no other jobs that can they're working on. Profession as a fisherman does not increase the savings of fishermen but it is sufficient to meet the daily needs of the family and sometimes even have to go into debt due to the lack of fish catches at sea. The lack of extension assistance and financial support from the government for fishermen in Maccini Sombala has made fishermen have to borrow from cooperatives and pawn gold to be able to operate their fishing boats.
\end{abstract}

Keywords: Development of social life, economy, fishing community, Maccini Sombala

\section{INTRODUCTION}

Socio-economic changes in a community are generally marked by new discoveries. In the fishing community, the new invention that is meant is the use of modern fishing gear, namely motorized machines so as to expand the fishing area by fishermen. To support the creation of a socio-economic change, especially in the fishing community in Maccini Sombala, Makassar city, infrastructure is needed such as a dock where the boat can dock or dock after fishing, settlements, road access, places of worship, schools, and various other facilities and infrastructure to support the activities of the fishermen and family members. [1]

Meanwhile, the process of economic change in fishing communities is marked by the decreasing number of fishermen who work individually using traditional lepa-lepa boats.[2] On the other hand, a pattern develops Group working relationship in the form of groups of fishermen, both catching fish, sea cucumbers and squid or other marine products. This is due to the narrowing of the fishing area for fishermen as a result of the high intensity of poisoning and fish bombing activities around the waters and the Makassar Strait. On the other hand, the growth and development of new economic forces controlled by those who are not fishermen, namely those who have large capital, then enter into work agreements in certain ways with fishermen for the catch obtained which is commonly referred to as the role Punggawa who has capital for service business.

Even with the polarization of the division of labor and the possibility of isolation of living quarters, due to the lack of access in fishing, making it difficult for the sustainability of fishing productivity due to poor facilities and access, this is a part of concern for researchers, where access to sea for the Maccini fishermen who are arrogant. very concerned about the consequences of the construction of the Tanjung Bunga Metro road which requires narrowing of the entry and exit routes for boats / transportation to go to sea. The polarization and isolation that have taken place are very detrimental to the fishermen in Maccini Sombala.

According to [3], this social and residential isolation affects other socio-cultural variables, which in turn will affect the development of fishing communities. This condition also results in low levels of education in many small-scale fishing environments in many developing countries. [4] Even in less isolated areas, social isolation causes fishermen and their families to respond negatively to formal education, compared to non-fishermen. For example, the inability of children of fishermen to dress properly in school encourages them to leave school faster. Apart from that, the existence of gender differences in the workforce is evidence that is often found in the basic system and distribution.

According to [5], the socio-economic aspects of a society are generally influenced by the aspects of the natural environment in which the community lives. Likewise, fishing communities have a unique rhythm of daily life, where the income they earn is not constant due to the variety of marine products that are obtained, depending on weather conditions, changing seasons and aspects of the surrounding natural environment as well as the ease of place 
of business. Dependence on this natural environment so that if the natural environment is disturbed, the survival of their family is also disturbed so that this aspect encourages fishermen to adjust their life activities with aspects that are completely limited and insufficient. Environmental changes that occur can affect the work behavior of fishermen in carrying out their work activities which have an impact on decreasing their income, causing a change of profession as happened in Batam Island. It is feared that the change in profession will have a negative impact on the pattern of their daily family life [6]

This is part of the research in carrying out research on the fishing community in Maccini Sombala, whose settlement is in the middle of Makassar city.

\section{METHOD}

The approach taken by the researcher is to use a descriptive qualitative approach. According to the theory of [7], the work steps are to describe an object, phenomenon, or social setting that is outlined in a narrative writing.

This means that the data and facts found in the field related to the socio-economic facts of fishermen Maccini Sombala are then collected through oral information from the fishermen, fishermen's families and the surrounding community, commonly referred to as informants. The data and facts are then described thoroughly and completely to illustrate what, why and how these changes have occurred in the fishing community in Maccini Sombala in Makassar City as well as being a research location.

The data collection technique was carried out in three ways, namely; through observation, in-depth interviews and documentation, while the techniques in data analysis are carried out repeatedly until the researcher obtains accurate data with three stages 1) data reduction stage, 2) data presentation and processing stage, 3) conclusion drawing stage [8]

\section{RESULT AND DISCUSSION}

\section{A. Social Life of Fishermen Maccini Sombala}

Before the construction of Jalan Metro Tanjung Bunga and elite housing and shopping facilities, the Maccini Sombala fishing community was very open and they could immediately see the sea as the edge of the fishing boat mooring area. Even access to the sea is very easy, without having to go through the Patompo river / canal which was built as a result of the construction of the Tanjung Bunga metro road, and the increasingly massive sea fill, the construction of hotels and shopping places (Transt Studio and Mall) but all this is not profitable for fishermen. Maccini Sombala is actually disastrous and detrimental to some of the fishermen in Maccini Sombala.

Lack of facilities for service businesses for the fishing community of Maccini Sombala seems isolated because they have to live along the edge of the canal and do not have a permanent pier, especially for small fishermen who use lepa-lepa and jolloro with small capacities that can enter the Patompo river / canal. The however, good road access and the existence of good school facilities certainly form a new social change, allowing fishermen's children to go to school by weaving free formal school education as part of the government program. The lighting facilities provided by PLN and the existing PDAM clean water facilities cannot be separated from the progress of Makassar City as a Metropolitan City.

In carrying out social activities, in the forms of social interaction related to associative, it can be divided into cooperation, accommodation, assimilation. This is inseparable from the complexity of an advancement in the current era of civilization.

\section{B. Economic Life of Fishermen}

The economic change in the Maccini Sombala fishing community is due to the fact that most of the fishermen are fishing for tuna, even though some other fishermen have changed professions, such as trading or other businesses due to the increasingly complex progress of the city of Makassar. Looking for tuna in the depths of the sea is the main goal of fishermen considering the price of tuna can reach IDR 150,000-200,000 / kg for large tuna for export market opportunities. However, only a few fishermen are fishing for tuna because of a lack of capital to go out to sea. In general, Maccini Sombala fishermen mostly look for fish by fishing, even though the sea area is around the shoreline.

The economic changes of the Maccini sombala fishing community, which are still in the traditional category, only seek to find fish only for food, not for sale in the market, but it is different for fishermen who have capital by looking for tuna / tuna. such as TV, sound system, VCD-DVD Player, mini compo, two-wheeled motorized vehicles, and various household needs are met quite adequately and a permanent home. This was emphasized by Ridwan as follows: "Sometimes I look for fish myself because I have Jolloro to look for mackerel / tuna which is equipped with an engine, usually we are at sea for 5-10 days but sometimes we are also crew members on a large Jolloro boat looking for sea cucumbers.[9]

In line with the information above, Dg Jaya another informant stated that:

"If you look for fish yourself you only need lepa-lepa, the result is only for the needs of the wife's children. But if you join Jolloro looking for sea cucumbers, the income you receive can be IDR 500,000 per ten days. The income isused to meet household needs"..[10]

The information above, confirmed by Rahmat, stated that: "The changes in the midst of the people of Makassar today are very clear. For example, in one house there are 
usually two to three family heads who live, and they are generally traditional fishermen using nets and lepa-lepa boats only looking for small fish in shallow waters near the shoreline, so their houses are on average narrow and not yet. permanent. The progress of development has not had much impact on us as fishermen, instead it makes fishermen worse off and even lose their jobs as fishermen because there is no longer access to the sea. because the sea stockpiling for large residential areas and shopping facilities and hotels makes us fishermen worse off and some have to leave work as fishermen and become construction workers "[11].

\section{Continue according to Dg Puji that:}

when compared to conditions less than ten years ago it was not like this. All activities are very good, access to the sea is very free without having to pass through the small and shallow Patompo canal, even to unload fish, all fishermen can go directly to the fishing dock of the Rajawali fish auction but now they can't anymore, almost all fishermen complain because access to the sea is less profitable for fishermen. [12]

Based on the three informants above, it can be understood that the socio-economic changes of the fishing community are measured by the level of income obtained from fishing activities or activities carried out, either individually or in groups in fishing, even the economic changes that occur greatly impact the progress of the city of Makassar as The metropolitan city, which part of the fishing community does not provide good economic progress, actually eliminates their work as fishermen, the choice of becoming mustard greens for fishermen who own large capital and seekers of sea cucumbers and squid by turning themselves into sawi (ship's crew). Fishermen's economic changes can be fast and slow, big or small, considering that everything is based on how much wage / salary they get from employing themselves on the fishing boat.

According to [13], this occurs because of the problems that have been covering fishermen related to small business capital and economic activities that are limited to one product only, namely only from marine products. Meanwhile, according to [14], fishing communities generally have a lower level of life than farmers or craftsmen.

This fact can be seen in the aspects of fishermen's life in fulfilling their daily needs that are not fulfilled, as well as the bad and slum aspects of fishermen settlement areas with an apprehensive visual appearance which are located very close to the beach.

According to [15] they state that in the process of fulfilling their daily needs, fishermen are always faced with harsh natural conditions so that a physically strong enough is needed. Fishermen who are relatively old and whose physical sap has begun to decline will gradually reduce the frequency of fishing and pursue other jobs that do not require physical strength.

Even economically in various fishing communities, women take a role in buying and selling fish. This division of labor sometimes provides benefits to the family, men take fish and women sell them. The role of fish traders makes women the main element in stabilizing the economy in various fishing environments, plus the ability of men to catch fish may only be intermittent while women can work all year round [16]. However, this condition is not found in the Maccini Sombala fishing community. The fisherwomen only focus on taking care of the household, giving birth and raising children, practically only on kitchen matters, although some of the women have to work outside matters related to catch management, for example being an auxiliary teacher or small trading. In the author's opinion, the existence of this right is the result of the pattern of labor relations and the sharing of the catch that has been monopolized by the owners of capital and the skipper.

\section{CONCLUSION}

The objective conditions of the findings in the field show that the process of social change in the Maccini Sombala fishing community begins with the construction of the Tanjung Bunga Metro road infrastructure so that it closes access to their fishing boat transportation roads and the loss and displacement of their fishing boat mooring areas in the Jenneberang river area which is $2 \mathrm{~km}$ from where they live. The construction of the Tanjung Bunga metro road infrastructure, hotels and housing, malls and flats does not make a big contribution to Maccini Sombala fishermen to interact with the sea, and build mutually beneficial socio-economic relationships, but instead narrows the movement of socio-economic change for Maccini fishermen. Sombala, where the river flow as a means of transportation for fishermen to go to the sea to find fish is very narrow and can no longer be passed by large fishing boats like Jolloro Pang-es, only small boats Lepa-lepa can pass through, thus keeping them away from the mooring area. and the pier where the fish auction is located.

\section{ACKNOWLEDGMENT}

We would like to extend highly appreciation to Universitas Negeri Makassar, the Faculty of Social Sciences for sponsoring the writing of this article and to the research informants, who provided valuable information in this research. Our warmest appreciation goes to Makassar State University, the Faculty of Social Sciences who sponsored this article and to the research informants, especially the fishermen, fishermen's wives, and community leaders who provided valuable information in this research. 


\section{REFERENCES}

[1] Depdiknas. Pendekatan Penelitian Kualitatif. Jakarta: Direktorat Jenderal Pendidikan Tinggi, 2008.

[2] Jufri. "Perubahan Sosial Ekonomi Komunitas Nelayan di Kelurahan Pulau Barrang Lompo Kecamatan Ujung Tanah Kota Makassar." 43-45. Makassar: Tesis Program Pasca Sarjana Universitas Negeri Makassar, 2011; 43.

[3] Supriharyono. Pelestarian dan Pengelolaan Sumber daya Alam di Wilayah Pesisir Tropis. Jakarta: Gramedia, 2000; 43.

[4] Sumitro. Kemiskinan di Perkotaan. Jakarta: Yayasan Obor Indonesia, 1991; 28.

[5] Pelestarian dan pengolahan Sumber Daya Alam di Wilayah Pesisir Tropis. Jakarta: Gramedia, 2002; 23.

[6] Satria. Pengantar Sosiologi Masyarakat Pesisir. Jakarta: Pustaka Cisendo, 2002: 54.

[7] Satori Dja'man, Komariah, Aan. Metodologi Penelitian Kualitatif. Bandung: Alfabeta, 2010; 28.

[8] Depdiknas. Pendekatan Penelitian Kualitatif. Jakarta: Direktorat Jenderal Pendidikan Tinggi, 2008 .

[9] Ridwan. "Interview." Makassar, 23 July 2020.

[10] Jaya. "Interview." Makassar, 24 July 2020.

[11] Rahmat. "Interview." Makassar, 28 July 2020.

[12] Jaya. "Interview." Makassar, 24 July 2020.

[13] Monintja, D dan R. Yusfiandayani. "Pemanfaatan Sumber Daya Pesisir dalam bidang Perikanan Tangkap.” 33-21. Bogor: Makalah disampaikan pada Pelatihan Pengolahan Wilayah Pesisir Terpadu, Kerjasama IPB-Proyel CRMP, 2001.

[14] Mubyarto. Nelayan dan Kemiskinan . Jakarta: Rajawali Press, 1998.

[15] Monintja, D. d. "Pemanfaatan Sumber Daya Pesisir dalam bidang Perikanan Tangkap.” Bogor: Makalah disampaikan pada Pelatihan Pengolahan Wilayah Pesisir Terpadu, Kerjasama IPB-Proyel CRMP., 2001; 32.

[16] Pramawardani, Sri. Pembangunan Sumber Daya Manusia Nelayan . Jakarta: Djembatan , 1979 